Liem, V. T., \& Hien, N. N. (2020). The impact of manager's demographic characteristics on prospector strategy, use of management accounting systems and financial performance. Journal of International Studies, 13(4), 54-69.

doi:10.14254/2071-8330.2020/13-4/4

\title{
The impact of manager's demographic characteristics on prospector strategy, use of management accounting systems and financial performance
}

\author{
Vo Tan Liem \\ University of Economics Ho Chi Minh City, \\ Viet Nam \\ liemncs@gmail.com \\ Nguyen Ngoc Hien \\ Industrial University of Ho Chi Minh City \\ Viet Nam \\ nguyenngocbien.qn@iuh.edu.vn \\ *Corresponding author
}

Abstract. Managers need the support of management accounting system (MAS) in making decisions and controlling activities. This article investigates the factors of CEO's personal characteristics that influence the choice of an appropriate prospector strategy and the intent of using MAS information. Besides, the moderating role of internal locus of control (ILOC) in such relationships was also examined in this research. The sample in this study includes CEOs of large and mid-sized companies in Vietnam. To test the hypotheses, we used the PLS-SEM method. The results indicate that all the effects are significant, except for the direct impact of age on financial performance and the moderating role of ILOC between education and the choices of prospector strategy. This study contributes to the accounting research field by confirming the role of managers' characteristics, recognizing the important role of MAS and helping managers in designing MAS suitable with the specific characteristics of CEO. As a result, managers can operate firms more effectively.

Keywords: education background, financial performance, internal locus of control, management accounting system.

JEL Classification: C1, M4, M1 


\section{INTRODUCTION}

Accounting information is useful information helping managers in their decision-making (Demski, 2013). MAS is a sub-control element of "an overall organisational control package" (Otley et al., 1995, p.421) and a controlling \& planning system that concentrates on reducing expected performance gaps before implementing the strategy and in the process of implementing the selected strategy (Downs, 1967). Therefore, MAS information is extremely important for the managers implementing strategies. However, the extent of MAS information use by managers in making decisions related to strategy implementation and performance improvement depends on several factors and also on the general context (Chenhall, 2003).

Demographic characteristics have an essential role not only in the results obtained from making managerial decisions but also for the level of success in implementing strategies (Jespersen \& Bysted, 2016). Some researchers have studied how technically oriented education of top management impacts on their style of using interactive MAS (Wijesinghe \& Samudrage, 2016). Others have studied how younger generation of managers with a different education is using innovative MAS in their strategy building (Naranjo-Gil et al., 2009; Wijesinghe \& Samudrage, 2016). However, in an emerging market such as Viet Nam, with rational resources in many perspectives, the use of innovative MAS is not suitable but traditional MAS is rather used instead. However, research studies concerning age and educational background of Vietnamese managers and their impact on the use of traditional MAS is very limited (Hiebl, 2014). In addition, studies investigating the use of MAS information are often not concerned with the financial performance achieved by organization (Naranjo-Gil \& Hartmann, 2006; Wijesinghe \& Samudrage, 2016). Notably, in Hambrick (2007) two moderator variables were updated in UET, but more recent studies have not really paid attention to this. For example, Hambrick \& Finkelstein (1987) indicated that ILOC has a moderator's role, but has not been interested in management accounting research (Wangrow et al., 2015).

Hambrick \& Mason (1984) were the first to introduce UET. Then, UET was reinforced and supported by Hambrick \& Finkelstein (1987), Hambrick et al. (2005), Hambrick (2007) and Hiebl (2014). Recently, in the field of management accounting, UET has been used more actively but still, in a very limited scope (Hiebl, 2014; Zor et al., 2019). This study examines two characteristics (education background and age) that affect the choice of strategies, using MAS information and financial performance of businesses. The moderating role of ILOC is also considered.

This research contributes to management accounting literature in many different ways. In the proposed framework, the authors examine the linkages between age and education background, MAS information use, the choices of prospector strategy, and financial performance for empirical analysis. The ILOC's moderating roles on some relationships are also examined. We used PLS-SEM to test the hypotheses (Wold, 1980). The measurement model and the structural model are assessed during the analysis process through two steps.

The next two sections present the background theory. Based on that, the theoretical model is presented. These sections end with the hypotheses to be tested. Following are the results and discussion. Limitations and directions for further studies are presented in the final section.

\section{LITERATURE REVIEW}

\subsection{Upper Echelon Theory (UET)}

After 1984, UET has much attention by researchers because demographic characteristics and psychological characteristics affecting the decision of high managers (Liem \& Hien, 2020; Nielsen, 2010). 


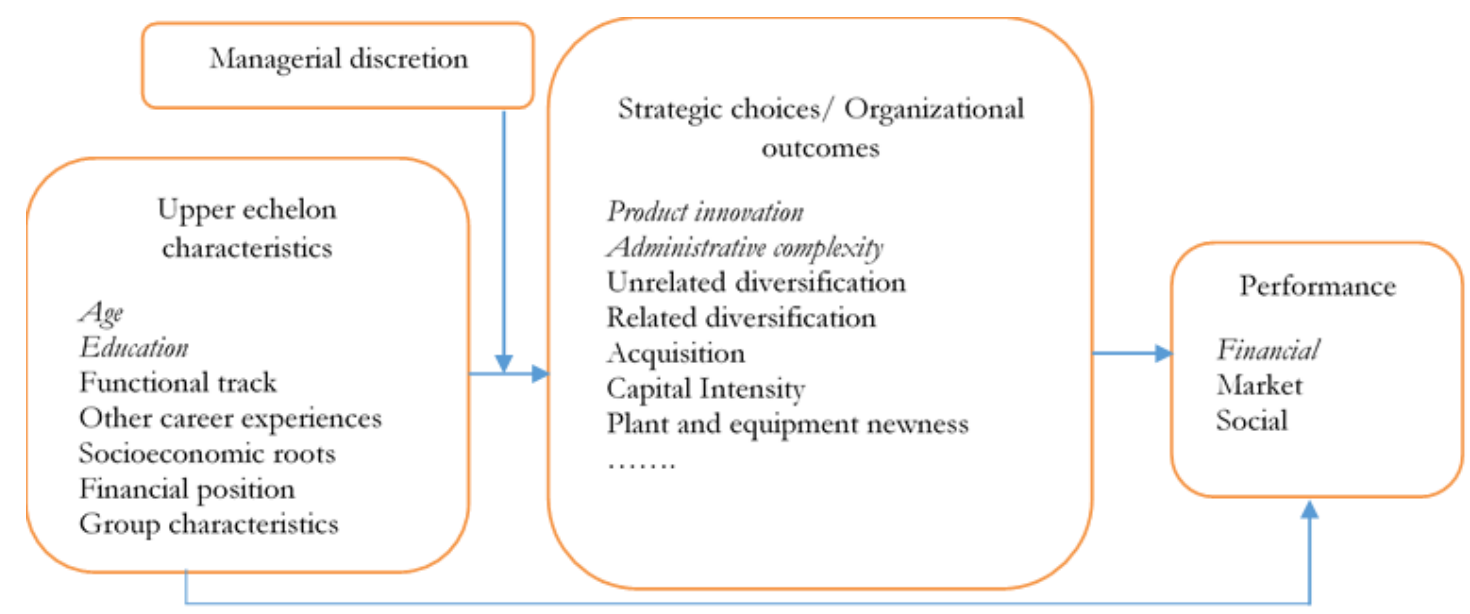

Figure 1. Model of UET (Adjusted from Hambrick \& Mason, 1984 and Heibl, 2014)

However, the method of measuring values and perceptions is complex and inaccurate. As a result, observation and measurement based on upper managers' demographics characteristics is used as an alternative method (Hambrick \& Mason, 1984). Managerial discretion has been updated for UET (Hambrick, 2007; Hambrick et al., 2005) and the relationship between upper managers and strategic choices/outcomes is moderated by managerial discretion.

\subsection{Demographic characteristics of managers}

The age of managers (Colombelli, 2015) and their education background (Damanpour \& Schneider, 2006) are considered to be the easiest factors to be observed and measured but they have a strong influence to the behavior of managers. More specifically, self-confidence, information use, risk-taking ability in decision making of upper managers are influenced by their age (Hambrick \& Mason, 1984). The education background is considered as a representative factor to build the psychology, which influences the way upper managers are awarded by the world around them and have appropriate information processing (Finkelstein et al., 1996; Hambrick \& Mason, 1984). The difference in academic background between business-oriented senior executives (economics, business, law, etc.) and other Non-business-oriented administrators (e.g. like engineering, physics and medicine, etc.) explains why many senior executives know the problems, have more knowledge or have better ways to solve the problems (Song, 1982).

\subsection{Prospector Strategy}

Research by Miles et al., (1978) divided organizational strategies into four categories: Defender, Prospector, Analyzers, and Reactors. Prospectors with characteristics like to respond quickly to environments, create and exploit new product and market development. They are also more dynamic than organizations in the same industry. During the analysis of each strategic trait, Miles et al., (1978) evaluated prospector strategy with the highest level of risk because this strategy needs a lot of corporate resources, and if the business does not control and not provide good supervise observation the financial harm will be potentially occurred.

\subsection{Management accounting system (MAS)}

Organization's outcome, a complex administrative or an aspect of organizational structure are characteristics of MAS (Chenhall, 2003; Chenhall \& Morris, 1986; Strauß \& Zecher, 2013). MAS has four 
dimensions including broad scope, timeliness, aggregation, and integration (Chenhall \& Morris, 1986; Liem $\&$ Hien, 2020). In prospective of scope, MAS would not only contain helpful information helping managers run organization, financial information in nature and essential history but also provide information that is external, non-financial, and future oriented. Characteristic of timeline information related to the frequency of reporting and rapid feedback (Liem \& Hien, 2020). The aggregation of information according to functional areas is characteristics of aggregation information, and finally, integration relates to the information sharing between sub-units (Liem \& Hien, 2020). UET believes that the use and design of a MAS can be expected to be influenced by the characteristics of the upper managers.

\subsection{Internal Locus of control (ILOC)}

ILOC is defined by the latitude of managerial action of decision maker (e.g., a top manager) in a known circumstance (Hambrick \& Finkelstein, 1987). Leaders will have a wider range of options when they have higher discretion (Campbell et al., 2012), with a broader latitude of action (Hambrick \& Abrahamson, 1995). Demographic characteristic of CEO, choice of strategy and a complex administrative system are moderated by managerial discretion's role (Liem \& Hien, 2020). Reflecting managerial discretion by individual factors are less studies (Wangrow et al., 2015). This study concentrated strategic behaviour (Powell et al., 2011), so characteristics of individual level is chosen to represent for managerial discretion. In characteristic of CEO, locus of control (LOC) is the psychological characteristics of managers that have an impact on their decision (Hambrick \& Finkelstein, 1987; Liem \& Hien, 2020). Two components in LOC are: internals and externals of LOC. CEOs have propensity with ILOC believes their own actions and efforts will affect to their livesand these characteristics will explain behavirors in strategic leadership (Liem \& Hien, 2020). From above reasons, this research chooses ILOC as a modesrate variable between characteristics of CEO and using MAS, choices of prospector strategy.

\subsection{Hypothesis development}

\subsubsection{Age, education background and choices of prospector strategy}

When age rises, flexibility falls. Besides, conservatism and resistance to change rise (Wiersema \& Bantel, 1992). Upper managers are less oriented towards big changes in organizations because of great level of risks. Especially, managers of higher ages are not capable for risky strategies (Seo \& Sharma, 2018) because they have been reduced their ability to assess new ideas quickly and integrated to make decisions to actions (Hambrick \& Mason, 1984). In contrast, younger upper managers have propensity to take risk and tend to implement new projects that can promote their careers in the future (Finkelstein et al., 1996). Upper managers with younger ages are more suited to higher risk strategies (Hambrick \& Mason, 1984). Therefore, lower age CEOs will favor to choose a risky strategy like prospector strategy (Miles et al., 1978).

H1a: The lower age of CEOs has positive impact on choices of prospector strategy.

Based on UET, the strategies selection in the typologies of Miles et al. (1978) will be influenced by the CEO's education background (Hambrick \& Mason, 1984; Pavlatos, 2012). A person with technically oriented education background generally has a different cognitive base compared to a person with business oriented (Hambrick \& Mason, 1984). However, the ability to excellently plan finances and effectively control business resources tends to favor managers with a business orientated background education (Naranjo-Gil \& Hartmann, 2007). In addition, they can also offer a good use of accounting information from a system administrative complexity (Rasid et al., 2014). So that, with business orientated education background, CEOs will have the ability to control risks better than uppers managers with non-business orientated 
education background. The above characteristics of business-oriented managers are essential for the choosing and pursuing of a risky strategy. As a result, uppers managers with business orientated education background will have more confidence and assertiveness in choosing prospector strategy.

H1b: CEOs with the more business orientated education background have positive impact on choices of prospector strategy.

\subsubsection{Age, education background and use of MAS information}

The higher the age of the managers, the lower the ability to use information and confidence to make decisions. Although, the searching for better information and the assessing the accuracy of information is better. At the same time, higher age CEOs take more time to make decisions (Taylor, 1975) so they don't need accounting information timely, broad scope, integrated and aggregated because they need long time to carefully consider before making decision, and they are more suitable to style of interactive use of MAS (Wijesinghe \& Samudrage, 2016). In the same view, decision-making, controlling and performance evaluation is significant negatively associated with CFO age (Pavlatos, 2012). In addition, to react quickly and create profits for businesses, CEOs must take risks in the decision-making process. This risk-taking is appropriate for CEO lower age so they are more risk management implementation (Lee \& Moon, 2016). Four perspectives of MAS have positive relationship with risk management activities (RMA) (Rasid et al., 2014). Besides, MAS provides information that is broad in scope, integrated, aggregated and be provided timely (Chenhall \& Morris, 1986).

H2a: The lower age of CEOs has positive impact on using MAS information.

Most upper managers are trained and provided with basic knowledge in the areas of accounting and finance, or generally the business sector. However, there are still differences in using MAS information to implement the strategy, which depend on the level of the main academic background that they have prepared for their career (Hiebl, 2014). Managers with a business orientated are more confident to use of financial information. Since, this type of MAS information related with administrator of organizations (Finkelstein et al., 1996; Song, 1982). Besides, with perceived environmental uncertainty, the timelier, integrated and aggregated accounting information helps managers timely response to the fluctuation of environment (Chenhall \& Morris, 1986). In contrary, managers with the propensity of technical orientated are positively related to use MASs with interactive style, positive use of innovative MASs (e.g. ABC, BSC, benchmarking) (Naranjo-Gil et al., 2009) and negative influence on using traditional MAS (Wijesinghe \& Samudrage, 2016).

H2b: CEOs with the more business orientated education background have positive impact on using MAS information.

\subsubsection{Age, education background and financial performance}

Higher age managers have less tolerance for both health and well-being (Child, 1974) or at least they are not good in creating new ideas or learning new decision-making behaviours (Chown, 1960). In contrast, lower age managers try to create new things, solve problems and make decisions in a new way, as well as accepting risks, which lead to a sudden financial change of organization (Hambrick \& Mason, 1984). Therefore, business performance is much higher or lower than the industry average because it depends on the success of the pursuing strategy (Hambrick \& Mason, 1984). In summary, lower age managers may be more taking risk, fast to accept new ideas and take actions, in the other face, higher age managers have more experience and more time to develop powerful parties. All of these advantages are necessary for decision making to achieve high performance. A recent research indicated that the higher age managers have positive impact on firm performance (Wei et al., 2005).

H3a: The higher age of CEO has positive impact on firm financial performance. 
The researches in medical, managers 's medical education toward take care and improve health for patient rather than the improvement financial performance of overall organization (Kurunmäki, 2004). Top managers with a non-business orientated education are more favour with the technical and operational process of the organization than managers with business orientated education. They are good at improving the content of processes (Finkelstein et al., 1996) and less towards improving the efficiencies of finance (Song, 1982). They also little focused on gains controls and efficiencies. In contrast, inclined toward the detailed control of outcomes of activities and processes has a positive relationship with manager in business education (Armstrong, 1987), because of the confidence, rely on distant and financial controls when managing the organization (Finkelstein et al., 1996; Song, 1982).

H3b: CEOs with the more business orientated education background have positive impact on firm financial performance.

\subsubsection{Choices of prospector strategy and financial performance}

Based on UET, the influence of choices strategy on performance is clearly shown. Therefore, there is a sufficient ground to indicate that a specific strategy like the choices of prospector strategy impact on firm financial performance. However, several studies had conflicting results about the choices of prospector influence on financial performance. Some researchers indicated that both financial performance and nonfinancial performance is influenced by prospector strategy (Köseoglu et al., 2013). In contrast, choices of strategy do not statistically significant influence financial performance (Chong \& Chong, 1997). Starting from these conflicts, however, relying on a positive mind set, choosing an innovative strategy like prospector strategy to meet the uncertainty environment impact on performance.

H4: The choice of prospector strategy have positive impact on firm financial performance.

\subsubsection{Choices of prospector strategy and use MAS information}

Organizations pursuing prospector strategy, information on a wide range of issues and timelier, integrative, aggregated and broader information areuseful for day-to-day decisions (Bouwens \& Abernethy, 2000; Chenhall \& Morris, 1986). Besides, to face with prospector strategy's risk mess, risk management activities is supported by MAS information (Soin \& Collier, 2013). In risk measurement, the more aggregated, reported and monitored about the risk, the more important roles of MAS, because in decision making process, MAS provide information for managers help them reduces the uncertainty (Winter, 2007). Risks deal with future events while broad scope MAS, which are future oriented, timely information, are required to respond to risk. Moreover, data integration is a key advantage for risk management, aggregated information summarizes informationthat expedite decision-making process (Rasid et al., 2014). The impact of certain decisions can be determined.

H5: Choice of prospector strategy haspositive impact on use MAS information.

\subsubsection{Use MAS information and financial performance}

Financial performance is impacted directly by using MAS information. Manager's knowledge can be having from MAS information when information can be processed and converted into knowledge of managers. At that time, for competitive advantages, MAS information becomes a unique strategic resource of managers. MAS can support managers' decisions to response to dynamic of environmental such as predicting the change of customer's need, facing to competitor's actions, continuously launched new products (Chenhall \& Morris, 1986). MAS is not only one part of management control system (Collier, 2015) but also "can be used to compare and contrast the results obtained by each activity" (Otley, 1980, p.64) "when implementing the strategy, thereby promoting the search for the wrong cause" (Downs, 1967), 
helps managers making decisions to change the allocation and the use of resources (Collier, 2015, p.39). So, with the useful features of MAS information help CEO to make decisions, that enhance the organization's performance.

H6: Using MAS information has positive impact on firm financial performance.

\subsubsection{The role of Internal Locus of control}

To have better in coping with complex and unstable environments, CEOs need higher ILOC (Miller \& Friesen, 1982) so that performance degradation will be minimized because they manage better in emotional exhaustion, reducing depersonalization, and increasing professional (Sirén et al., 2018). Moreover, with the difference of leadership abilities, CEO can use persuasion more often to influence others' behaviour, and they trust in their capacity to influence the environment (Boone et al., 1996). In Wangrow et al. (2015)'s review indicated that because of the riskiness of this strategy, the more firms' choice and pursuing prospector strategy, the more managerial discretion. Therefore, the more the confidence of CEO, the more the prospector strategy is choiced by CEO. Based on H1a, H1b; as lower age of CEO and education background of CEO are business, CEO increases choices of prospector strategy so that relationship between lower age, business orientated education and choice of prospector strategy greatly increases when ILOC of the CEO increases.

H7a: CEO with the more ILOC propensity, lower age impact on choice of prospector stratey will be stronger.

H7b: CEO with the more ILOC propensity, business orientated education background impact on choice of prospector stratey will be stronger.

When executing the selected prospector strategy, control system to control whether or not the work is being done according to the plan and timely action if work didn't like they expected. However, this system must suitable with their characteristics. When information is relevant and when it is not useful for managers oriented on ILOC (Lefcourt, 1982). Between different parts of the organization, the ability of MAS can be synthesized and integrated information (Collier, 2015, p.42). So, MAS is seen as a preeminent technology from the creation of strategies to implementing them and providing clear accountability for integrating diverse activities (Otley et al., 1995), also we can say that if the more increase of ILOC's moderate role, MAS information is perceived to be useful and relevant by CEO. Based on hypothesis (H2a, H2b), above, as lower age of CEO and education background of CEO are business orientated, CEO increases using frequency of MAS information so that the relationship between lower age, business orientated education and using MAS information increases when ILOC of CEO increases.

H7c: CEO with the more ILOC propensity, lower age impact on using MAS information will be stronger.

H7d: CEO with the more ILOC propensity, business orientated education background impact on using MAS information will be stronger.

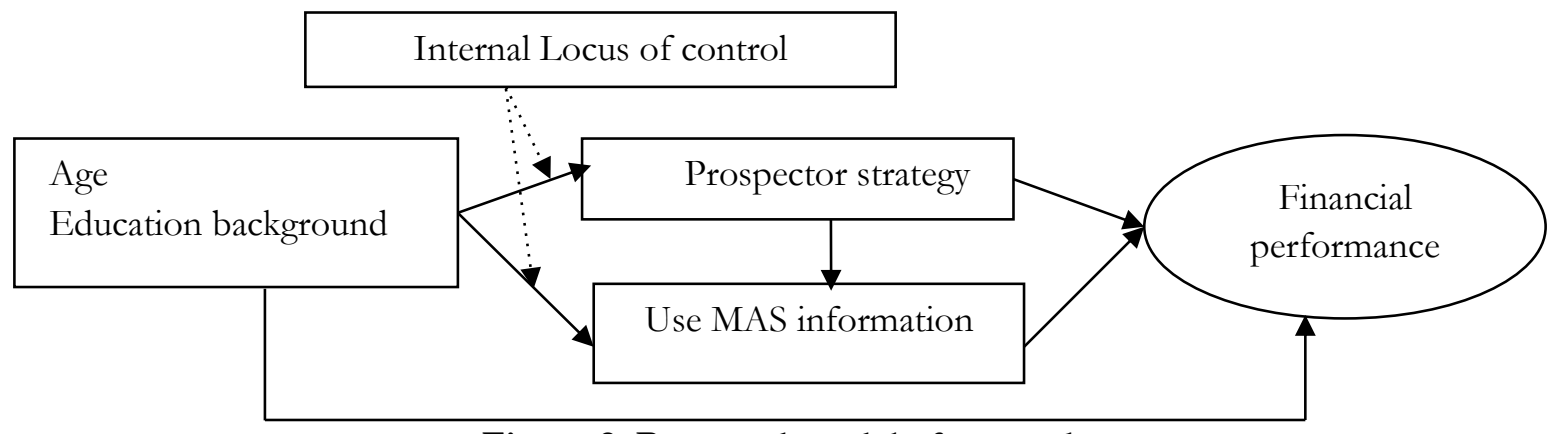

Figure 2. Proposed model of research

Source: Own elaboration 


\section{METHODOLOGY}

\subsection{Measurement}

The exact age is used to measure the age of CEO (Pavlatos, 2012). The measurement of Naranjo-Gil et al. (2009) is used to measure CEO's educational background. Each CEO was asked to state their educational background in years of studies (college, bachelors, master degrees and courses attended) in two streams: (1) business orientated and (2) non-business orientated. Following, the variable "educational background" is measured by dividing the years studied in business programs with the total years of studies.

The MAS is adapted from the scale of Chenhall \& Morris (1986), Agbejule (2005). As such, CEO was required to indicate the rate "extent of use" of MAS information in four perspectives consist of integration (four items), broad scope (four items), aggregation (three items) and timeliness (four items) in each organization. Prospector strategy is measured using the scale of 1-7 from (Segev, 1987). This research based on Mueller \& Thomas (2001)'s measurement of LOC was adapted from the scale of Rotter (1966)'s. Firm performance is adapted from the scale of Calantone et al. (2002). This measurement scale includes five indicators: Return on sales (ROS), Return on investments (ROI), Sales growth, Return on assets (ROA) and Overall profitability.

\subsection{Sample and data}

This study is conducted in Vietnam, an emerging economy. A data set of 234 large and medium firms is featured. To have enough characteristics of CEOs and firms. E-mail surveys are then distributed to CEO from different Vietnamese business organizations.

CEOs of business organizations in Vietnam are chosen to send e-mails surveys. Based on e-mail addresses is collected from websites of businessperson association, department of planning and investment, and websites of businesses. 2,500 surveys were distributed to CEOs. An invitation letter with a link to the web-based survey was sent to CEOs' email addresses. This method has weaknesses of response errors (respondents provide inaccurate data) and non-response errors (target respondents do not reply). Nonresponse may cause a problem in the estimates of a survey if there are systematic differences between respondents and non-respondents. To deal with this problem, appropriate procedures were carried out, such as contacting the right person, following-up by sending reminder emails. Reminder mail was sent to the respondent every 2 weeks for 2 months after sending, in order to encourage feedback. Out of the 562 managers who clicked on the link to participate, only 317 answered the questions; 287 out of these 317 participants completed the questionnaires and submitted them; 38 responses from CEOs in small enterprises were excluded; 15 missing cases were removed from the data. Finally, 234 cases were used for data analysis providing a response rate of $41.8 \%$ (234 eligible responses $/ 562$ cases agreed to participate).

\section{EMPIRICAL RESULTS}

We used SPSS24 for basic statistical analysis. To be primarily for path analysis, we used Partial least squares-structural equation modelling (PLS-SEM) (Wold, 1980).

\subsection{Respondents Profile}

A data set of 234 large and medium firms is featured. The sample is restricted to this kind of firm only as it possesses sufficient financial resources to operate and the need to design a management accounting system. 
Demographic characteristics

\begin{tabular}{|c|c|c|c|c|c|}
\hline Gender & Freq. & $\mathbf{0}$ & Education Background & Freq. & $\mathbf{\%}$ \\
\hline Male & 147 & 63 & Pre-undergraduates & 18 & 8 \\
\hline Female & 87 & 37 & Undergraduates & 123 & 53 \\
\hline Total & $\mathbf{2 3 4}$ & $\mathbf{1 0 0}$ & Post-graduates & 93 & 40 \\
\hline $\begin{array}{c}\text { Tenure } \\
\text { (years) }\end{array}$ & & & Total & $\mathbf{2 3 4}$ & $\mathbf{1 0 0}$ \\
\hline $1-5$ & 27 & 12 & Age & & \\
\hline $6-10$ & 82 & 35 & $18-29$ & 93 & 6 \\
\hline $11-15$ & 67 & 29 & $30-49$ & 98 & 42 \\
\hline $15-20$ & 48 & 21 & $50-64$ & 28 & 12 \\
\hline$>20$ years & 10 & 4 & $>64$ & $\mathbf{2 3 4}$ & $\mathbf{1 0 0}$ \\
\hline Total & $\mathbf{2 3 4}$ & $\mathbf{1 0 0}$ & Total & & \\
\hline
\end{tabular}

Source: Own development

Table 1 show that, the final sample reflects 63 percent of male CEOs and 37 percent of female CEOs. CEOs have an average working time of 12 years. This shows that they have enough degree of influence over the organization in which they are working. The sample comprises 8 percent pre-undergraduates, 53 percent undergraduates, and 40 percent post-graduates. it shows most CEO education background are undergraduates. The age ranges from 30-64 for the highest percentage of the respondents.

\subsection{Measurement model}

Harman's single factor test was employed to evaluate the common method bias. All measurement constructs, we accompanied Un-rotated factor analysis (Excluding education and age) extracted 7 factors. The first factor accounts for $35.12 \%(<50 \%)$ of the total cumulative variance of the 7 factors is $76.6 \%$. Thus, the Common method bias in this study is not a serious problem (Podsakoff et al., 2003).

Internal reliability is used to assessed scale reliability, Cronbach's alpha and rhoA is used to evalue composite reliability (Dijkstra \& Henseler, 2015; Nunnally \& Bernstein, 1994; Sarstedt et al., 2017). Outer loading of items greater than 0.7 and AVE of contructs greater than 0.5 are acceptable (Hair et al., 2016) are conditions of convergent validity. Bootstrapping 5000 timses was performed to test the results of the measurement model and to test the research hypothesis (Hair et al., 2016).

Table 2

Reliability and convergent validity of the scales

\begin{tabular}{|l|c|c|c|c|}
\hline \multicolumn{1}{|c|}{ Construct } & Cronbach's alpha & CR & rhoA & AVE \\
\hline 1. Age & 1.000 & 1.000 & 1.000 & 1.000 \\
\hline 2. Aggregation & 0.767 & 0.851 & 0.763 & 0.581 \\
\hline 3. Broad scope & 0.896 & 0.928 & 0.898 & 0.763 \\
\hline 4. Education & 1.000 & 1.000 & 1.000 & 1.000 \\
\hline 5. Financial performance & $0.834^{*}$ & $0.884^{*}$ & $0.866^{*}$ & $0.787^{*}$ \\
\hline 6. Integration & 0.873 & 0.911 & 0.892 & 0.807 \\
\hline 7. MAS information & 0.878 & 0.922 & 0.891 & 0.759 \\
\hline 8. Prospector strategy & 0.863 & 0.901 & 0.887 & 0.786 \\
\hline 9. Timeline & 0.841 & 0.876 & 0.857 & 0.728 \\
\hline
\end{tabular}

Note: * Reject ROS

Source: Own development

The test results of reliability and convergence value in Table 2 show that the cronbach's alpha, Composite reliability coefficient is in the range $[0.7 ; 0.95]$ and tho coefficient greater than 0.5 . This shows 
the scales for measuring the concepts in the model to reach reliability. the AVE and outer loadings values are used to evaluate the convergence value of the scale. ROS variable has outer loading $=0.46<0.5$, so remove this variable from the Financial performance. The test results show that the AVE value of the scales are greater than 0.5 and the outer loadings of the observed variables are greater than 0.7 , so the scales reach convergence value (Figure 3).

Cross-loading factor coefficient, HTMT ratio and Fornell-Larker criterionis is used to evaluate discriminant values of concepts (Dijkstra \& Henseler, 2015; Hair et al., 2016). Test results cross-loading show, Cross-loading coefficient in its structure is much larger than in other structures. Besides the results of Fornell-Larcker criterion (Table 3) and factor HTMT (Table 4) present that the scale ensures discriminating value.

Table 3

Fornell-Larcker criterion

\begin{tabular}{|l|c|c|c|c|c|c|c|c|c|}
\hline \multicolumn{1}{|c|}{ Constructs } & 1 & 2 & 3 & 4 & 5 & 6 & 7 & 8 & 9 \\
\hline 1. Age & $\mathbf{1 . 0 0 0}$ & & & & & & & & \\
\hline 2. Aggregation & 0.312 & $\mathbf{0 . 9 1 7}$ & & & & & & & \\
\hline 3. Broad scope & 0.346 & 0.611 & $\mathbf{0 . 8 7 3}$ & & & & & & \\
\hline 4. Education & 0.629 & 0.305 & 0.316 & $\mathbf{1 . 0 0 0}$ & & & & & \\
\hline 5. Financial performance & 0.546 & 0.215 & 0.149 & 0.285 & $\mathbf{0 . 6 9 5}$ & & & & \\
\hline 6. Integration & 0.226 & 0.636 & 0.662 & 0.305 & 0.068 & $\mathbf{0 . 8 9 7}$ & & & \\
\hline 7. MAS information & 0.362 & 0.638 & 0.661 & 0.368 & 0.185 & 0.622 & $\mathbf{0 . 8 1 2}$ & & \\
\hline 8. Prospector strategy & 0.625 & 0.393 & 0.408 & 0.655 & 0.544 & 0.291 & 0.438 & $\mathbf{0 . 8 8 6}$ & \\
\hline 9. Timeline & 0.428 & 0.647 & 0.651 & 0.396 & 0.239 & 0.630 & 0.697 & 0.487 & $\mathbf{0 . 9 0 0}$ \\
\hline
\end{tabular}

Source: Own development

Results from run bootstrap 5.000 times, factors have statistically significant, with a significance level less than $5 \%$ (p-value $<0,05$, test $\mathrm{t} 2$-tails).

Table 4

Heterotrait-Monotrait Ratio (HTMT)

\begin{tabular}{|l|c|c|c|c|c|c|c|c|c|}
\hline \multicolumn{1}{|c|}{ Constructs } & 1 & 2 & 3 & 4 & 5 & 6 & 7 & 8 & 9 \\
\hline 1. Age & & & & & & & & & \\
\hline 2. Aggregation & 0.312 & & & & & & & & \\
\hline 3. Broad scope & 0.369 & 0.786 & & & & & & & \\
\hline 4. Education & 0.629 & 0.318 & 0.334 & & & & & & \\
\hline 5. Financial performance & 0.670 & 0.253 & 0.232 & 0.374 & & & & & \\
\hline 6. Integration & 0.226 & 0.913 & 0.839 & 0.317 & 0.188 & & & & \\
\hline 7. MAS information & 0.368 & 0.895 & 0.934 & 0.375 & 0.255 & 0.880 & & & \\
\hline 8. Prospector strategy & 0.842 & 0.418 & 0.439 & 0.669 & 0.679 & 0.307 & 0.454 & & \\
\hline 9. Timeline & 0.442 & 0.781 & 0.712 & 0.410 & 0.274 & 0.768 & 0.749 & 0.513 & \\
\hline
\end{tabular}

Source: Own development

\subsection{Structural model}

Variance-inflating factor (VIF) is used to evaluated multicollinearity between independence variables. The scale of Prospector strategy had VIF $=0.253$ (lower 0.5 ), so it appeared multicollinearity but trivial, can be acceptable (Hair et al., 2016). The remaining scales have VIF $<2$, so they didn't appear to be 
multicollinearity.

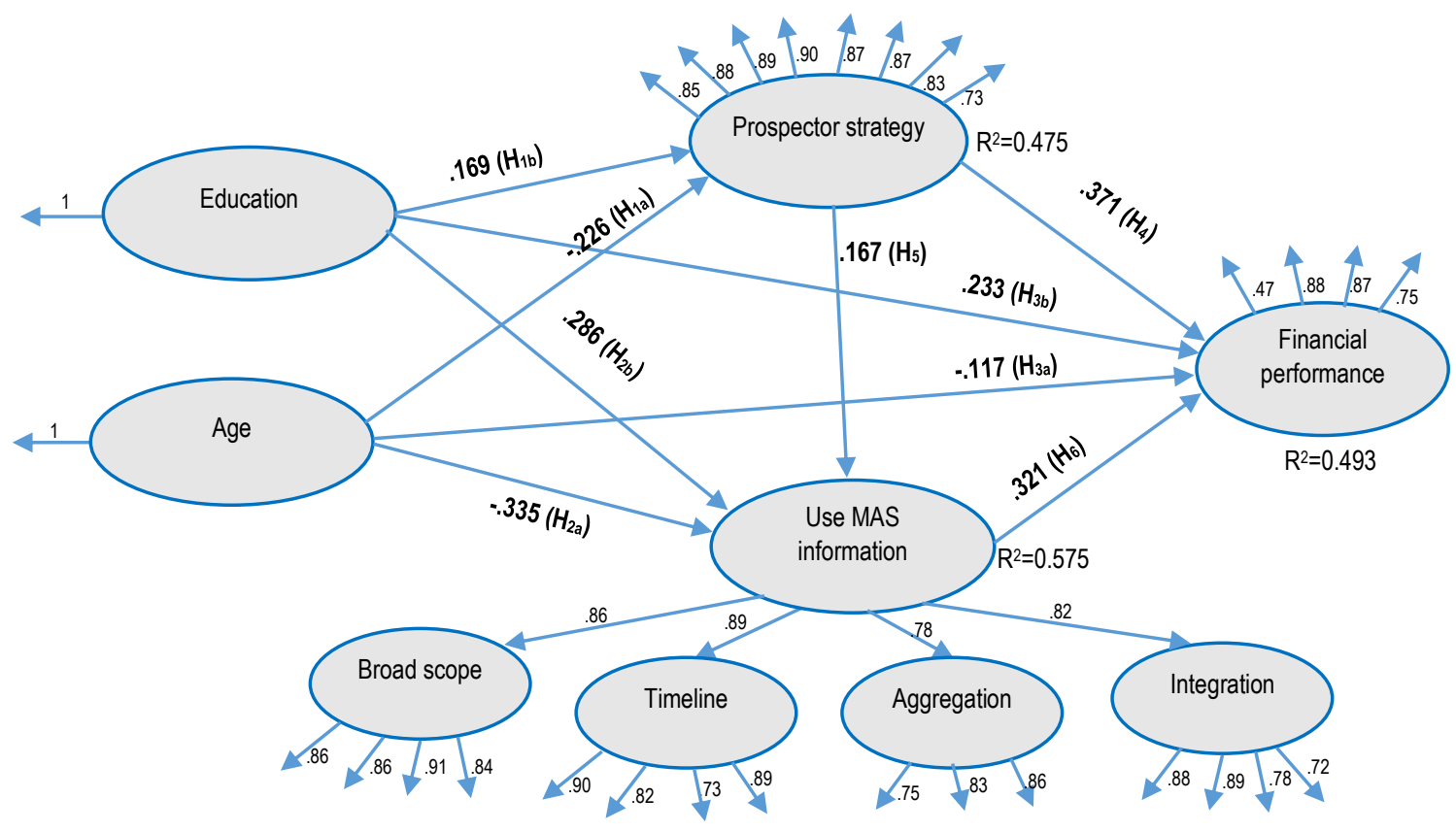

Figure 3. The results of theoretical model analysis by PLS-SEM

Source: Own development

$\mathrm{R}^{2}$ value is calculated to assess the predictive capability of dependence variables (Hair et al., 2016). The results in table $5, \mathrm{R}^{2}$ value of MAS information is 0.575 , Prospector strategy is 0.475 and Financial performance is 0.493 , which can be considered to have an enough level of prediction (Hair et al., 2016). Besides, predictive relevance $\left(\mathrm{Q}^{2}\right)$ is also used to evaluate the out-of-sample predictive power. The factor $\mathrm{Q}^{2}$ of dependence variables is greater than 0 . Consequently, it supports the predictive power of the model. Results of testing the theoretical model with bootstrap 5.000 times in model PLS-SEM show, exclude the relationship between Age and Financial Performance is not statistically significant. Besides, the remaining relationships in the theoretical model are statistically significant with reliability greater than $95 \%$ (Table 5).

Table 5

Hypotheses testing results

\begin{tabular}{|l|c|c|c|c|}
\hline \multicolumn{1}{|c|}{ Relationships } & Coefficient & t-value & p-value & Hypothesis \\
\hline H1a: Age $\rightarrow$ Prospector strategy & -0.226 & 6.375 & 0.000 & Support \\
\cline { 2 - 5 } H1b: Edu $\rightarrow$ Prospector strategy & 0.169 & 2.508 & 0.037 & Support \\
\hline H2a: Age $\rightarrow$ MAS information & -0.335 & 8.817 & 0.000 & Support \\
\cline { 2 - 5 } H2b: Edu $\rightarrow$ MAS information & 0.286 & 4.861 & 0.000 & Support \\
\hline H3a: Age $\rightarrow$ Financial Performance & -0.117 & 1.101 & 0.271 & Reject \\
\cline { 2 - 5 } H3b: Edu $\rightarrow$ Financial Performance & 0.233 & 4.623 & 0.000 & Support \\
\hline H4: Prospector $\rightarrow$ Financial Performance & 0.371 & 6.422 & 0.000 & Support \\
\hline H5: Prospector $\rightarrow$ MAS information & 0.167 & 5.029 & 0.000 & Support \\
\hline H6: MAS information $\rightarrow$ Financial Performance & 0.321 & 6.978 & 0.000 & Support \\
\hline$R^{2}$ MAS information $=0.575$ & $Q^{2}$ MAS information $=0.356$ & \\
R $^{2}$ Prospector strategy $=0.475$ & $Q^{2}$ Prospector strategy $=0.357$ & \\
$R^{2}$ Financial performance $=0.493$ & $Q^{2}$ Financial performance $=0.315$ & \\
\hline
\end{tabular}

Source: Own development 
Testing the moderator of Internal Locus of control is a major objective in this research. To test the role of the moderator variable, first, evaluating the measurement model in the presence of the Internal locus of control variable. The results indicate that the measurement concepts are reliable and valuable. Next, to assess the impact of the moderator variable, the two-stage approach (Chin et al., 2003) was applied. The first phase was used to estimate the main impact model, while the second phase multiplied the moderator variables and exogenous variables to measure interaction terms (Age $\mathrm{x}$ Internal locus of control; Edu $\mathrm{x}$ Internal locus of control; Age x Internal locus of control; Edu x Internal locus of control).

Table 6

Tests for moderating effects

\begin{tabular}{|l|c|c|c|}
\hline & Coefficient & $\mathrm{R}^{2}$ & $\mathrm{p}$-value \\
\hline Age $\rightarrow$ Prospector strategy & -0.215 & 0.493 & 0.000 \\
\hline Age $x$ ILOC $\rightarrow$ Prospector strategy & 0.102 & & 0.000 \\
\hline ILOC $\rightarrow$ Prospector strategy & 0.257 & & 0.000 \\
\hline Edu $\rightarrow$ Prospector strategy & 0.122 & 0.420 & 0.043 \\
\hline Edu x ILOC $\rightarrow$ Prospector strategy & 0.039 & & 0.203 \\
\hline ILOC $\rightarrow$ Prospector strategy & 0.197 & & 0.000 \\
\hline Age $\rightarrow$ MAS information & -0.316 & 0.592 & 0.000 \\
\hline Age x ILOC $\rightarrow$ MAS information & 0.096 & & 0.024 \\
\hline ILOC $\rightarrow$ Prospector strategy & 0.215 & & 0.000 \\
\hline Edu $\rightarrow$ MAS information & 0.264 & 0.576 & 0.000 \\
\hline Edu x ILOC $\rightarrow$ MAS information & 0.125 & & 0.000 \\
\hline ILOC $\rightarrow$ Prospector strategy & 0.278 & & 0.000 \\
\hline
\end{tabular}

Source: Own development

Results in Table 6 shows that the ILOC does not play a moderator role in the relationship between Education and Prospector strategy ( $\mathrm{p}$ - value $=0.203>0.05$, Reject hypothesis H7b - See table 6 ). The remaining hypotheses are statistically significant $(\mathrm{p}$-value $<0.05)$.

\section{CONCLUSION}

\subsection{Theoretical implications}

In this study, some theoretical implications as follows: Firstly, the impact direct between demographic characteristics (age, education) of CEO and choices of prospector strategy (Hambrick \& Mason, 1984; Song, 1982; Wijesinghe \& Samudrage, 2016), MAS (e.g. Wijesinghe \& Samudrage (2016); Naranjo-Gil et al. (2009); Pavlatos (2012), financial performance (Hambrick \& Mason, 1984; Hiebl, 2014) was examined. However, the impact of age on financial performance is not significant. This result agrees with research of Hambrick \& Mason (1984) and Bertrand \& Schoar (2003) because they concluded that higher or lower performance depends on the success of chose prospector strategy. This study also supports for positive influence of MAS on financial performance.

Secondly, the moderator role of ILOC between age, education and choices of prospector strategy; use MAS information was tested, which had not been examined in previous studies. Although, the moderate role of ILOC of CEO in relationship between education background and choices of prospector strategy is not supported but this study provides. Further, through empirical evidence, the result in this study indicated the importance role of CEO's ILOC in decision making choices of prospector strategy to enhance the financial performance of firms in an emerging economy like Viet Nam.

Finally, this study helps to reduce the shortage of researches at age, education of CEO/strategy/accounting interface (Hiebl, 2014; Naranjo-Gil \& Hartmann, 2006, 2007; Pavlatos, 2012; 
Zor et al., 2019). More obviously, model representsthe combination between age and education of CEO, a personality characteristic (ILOC), and a marketing variable (choices of prospector strategy) and an accounting variable (the use of MAS) in the theoretical model.

\subsection{Managerial implication}

The model of Hambrick and Mason was reinforced by this study 's result. So, this study also confirmed the applicability of UET in Vietnamese environment. There are some managerial implication: Firstly, with the CEO 's ILOC, it enhanced: (1) the negative effect from age to the choice of prospector strategy, from age to use MAS information; (2) the positive effect from education background (business orientation) to the choice of prospector strategy, from education background (business orientation) to use MAS information. It showed that the demand for using MAS information is also affected by CEO's ILOC. Therefore, when designing MAS in a firm, beside CEO 's demographic characteristics, MAS designer need to pay attention to ILOC (a psychological feature). In addition, when the organization was determined to pursue the strategy prospector, this type of strategy must be suitable with CEO 's demographic characteristics (lower age and business orientation) and ILOC. Secondly, to gain competitive advantages, designing and using MAS will help to make implication the clearly way to implement it. In this view, CEO 's business orientation education background combine with suitable stratey (prospector strategy) is basic to make it become reality by enhance firm performance. Finally, two benefit from the results of this study are: (1) CEO 's designing and using MAS will be guidance and (2) towarding enhanced performance, prospector strategy should be suitable with CEO 's characteristics (age, education background, ILOC).

\section{ACKNOWLEDGEMENT}

Researches would like to thanks University of Economics Ho Chi Minh City, Industrial University of Ho Chi Minh City, Vietnam for their grand help us to completed this study.

\section{REFERENCES}

Agbejule, A. (2005). The relationship between management accounting systems and perceived environmental uncertainty on managerial performance: a research note. Accounting and Business Research, 35(4), 295-305.

Armstrong, P. (1987). Engineers, management and trust. Work, Employment and Society, 1(4), 421-440.

Bertrand, M., \& Schoar, A. (2003). Managing with style: The effect of managers on firm policies. The Quarterly Journal of Economics, 118(4), 1169-1208.

Boone, C., De Brabander, B., \& Van Witteloostuijn, A. (1996). CEO locus of control and small firm performance: An integrative framework and empirical test. Journal of Management Studies, 33(5), 667700 .

Bouwens, J., \& Abernethy, M. A. (2000). The consequences of customization on management accounting system design. Accounting, Organizations and Society, 25(3), 221-241.

Calantone, R. J., Cavusgil, S. T., \& Zhao, Y. (2002). Learning orientation, firm innovation capability, and firm performance. Industrial Marketing Management, 31(6), 515-524.

Campbell, J. T., Campbell, T. C., Sirmon, D. G., Bierman, L., \& Tuggle, C. S. (2012). Shareholder influence over director nomination via proxy access: Implications for agency conflict and stakeholder value. Strategic Management Journal, 33(12), 1431-1451.

Chenhall, R. H. (2003). Management control systems design within its organizational context: findings from contingency-based research and directions for the future. Accounting, Organizations and Society, 28(2-3), 
127-168.

Chenhall, R. H., \& Morris, D. (1986). The impact of structure, environment, and interdependence on the perceived usefulness of management accounting systems. Accounting Review, 16-35.

Child, J. (1974). Managerial and organizational factors associated with company performance part I. Journal of Management Studies, 11(3), 175-189.

Chin, W. W., Marcolin, B. L., \& Newsted, P. R. (2003). A partial least squares latent variable modeling approach for measuring interaction effects: Results from a Monte Carlo simulation study and an electronic-mail emotion/adoption study. Information Systems Research, 14(2), 189-217.

Chong, V. K., \& Chong, K. M. (1997). Strategic choices, environmental uncertainty and SBU performance: a note on the intervening role of management accounting systems. Accounting and Business Research, 27(4), 268-276.

Chown, S. M. (1960). A factor analysis of the Wesley Rigidity Inventory: its relationship to age and nonverbal intelligence. The Journal of Abnormal and Social Psychology, 61(3), 491.

Collier, P. M. (2015). Accounting for managers: Interpreting accounting information for decision making. John Wiley \& Sons.

Colombelli, A. (2015). Top management team characteristics and firm growth. International Journal of Entrepreneurial Behavior \& Research.

Damanpour, F., \& Schneider, M. (2006). Phases of the adoption of innovation in organizations: effects of environment, organization and top managers 1. British Journal of Management, 17(3), 215-236.

Demski, J. (2013). Managerial uses of accounting information. Springer Science \& Business Media.

Dijkstra, T. K., \& Henseler, J. (2015). Consistent partial least squares path modeling. MIS Quarterly, $39(2)$.

Downs, A. (1967). Inside Bureaucracy. In Santa Monica. MA:Little Brownand Company.

Finkelstein, S., Hambrick, D., \& Cannella, A. A. (1996). Strategic leadership. St. Paul: West Educational Publishing.

Hair Jr, J. F., Hult, G. T. M., Ringle, C., \& Sarstedt, M. (2016). A primer on partial least squares structural equation modeling (PLS-SEM). Sage publications.

Hambrick, D. C. (2007). Upper echelons theory: An update. Academy of Management Briarcliff Manor, NY 10510.

Hambrick, D. C., \& Abrahamson, E. (1995). Assessing managerial discretion across industries: A multimethod approach. Academy of Management Journal, 38(5), 1427-1441.

Hambrick, D. C., \& Finkelstein, S. (1987). Managerial discretion: A bridge between polar views of organizational outcomes. Research in Organizational Behavior.

Hambrick, D. C., Finkelstein, S., \& Mooney, A. C. (2005). Executive job demands: New insights for explaining strategic decisions and leader behaviors. Academy of Management Review, 30(3), 472-491.

Hambrick, D. C., \& Mason, P. A. (1984). Upper echelons: The organization as a reflection of its top managers. Academy of Management Review, 9(2), 193-206.

Hiebl, M. R. W. (2014). Upper echelons theory in management accounting and control research. Journal of Management Control, 24(3), 223-240.

Jespersen, K. R., \& Bysted, R. (2016). Implementing new product development: A study of personal characteristics among managers. International Journal of Innovation Management, 20(03), 1650043.

Köseoglu, M. A., Topaloglu, C., Parnell, J. A., \& Lester, D. L. (2013). Linkages among business strategy, uncertainty and performance in the hospitality industry: Evidence from an emerging economy. International Journal of Hospitality Management, 34, 81-91.

Kurunmäki, L. (2004). A hybrid profession-the acquisition of management accounting expertise by medical professionals. Accounting, Organizations and Society, 29(3-4), 327-347.

Lee, W. S., \& Moon, J. (2016). Determinants of CEO strategic risk-taking in the airline industry. Tourism Management Perspectives, 18, 111-117.

Lefcourt, H. M. (1982). Locus of control: Current trends in theory and research (2nd Editio). Psychology Press. https://doi.org/https://doi.org/10.4324/9781315798813

Liem, V. T., \& Hien, N. N. (2020). Exploring the impact of Dynamic Environment and CEO’s Psychology Characteristics on Using Management Accounting System. Cogent Business \& Management, just-accepted, 1712768.

Miles, R. E., Snow, C. C., Meyer, A. D., \& Coleman Jr, H. J. (1978). Organizational strategy, structure, and 
process. Academy of Management Review, 3(3), 546-562.

Miller, D., \& Friesen, P. H. (1982). Innovation in conservative and entrepreneurial firms: Two models of strategic momentum. Strategic Management Journal, 3(1), 1-25.

Mueller, S. L., \& Thomas, A. S. (2001). Culture and entrepreneurial potential: A nine country study of locus of control and innovativeness. Journal of Business Venturing, 16(1), 51-75.

Naranjo-Gil, D., \& Hartmann, F. (2006). How top management teams use management accounting systems to implement strategy. Journal of Management Accounting Research, 18(1), 21-53.

Naranjo-Gil, D., \& Hartmann, F. (2007). Management accounting systems, top management team heterogeneity and strategic change. Accounting, Organizations and Society, 32(7-8), 735-756.

Naranjo-Gil, D., Maas, V. S., \& Hartmann, F. G. H. (2009). How CFOs determine management accounting innovation: an examination of direct and indirect effects. European Accounting Review, 18(4), 667-695.

Nielsen, S. (2010). Top management team diversity: A review of theories and methodologies. International Journal of Management Reviews, 12(3), 301-316.

Nunnally, J. C., \& Bernstein, I. H. (1994). Psychological theory. New York: McGraw-Hill.

Otley, D., Broadbent, J., \& Berry, A. (1995). Research in management control: an overview of its development. British Joumal of Management, 6, S31-S44.

Otley, D. T. (1980). The contingency theory of management accounting: achievement and prognosis. In Readings in accounting for management control (pp. 83-106). Springer.

Pavlatos, O. (2012). The impact of CFOs' characteristics and information technology on cost management systems. Journal of Applied Accounting Research.

Podsakoff, P. M., MacKenzie, S. B., Lee, J.-Y., \& Podsakoff, N. P. (2003). Common method biases in behavioral research: a critical review of the literature and recommended remedies. Journal of Applied Psychology, 88(5), 879.

Powell, T. C., Lovallo, D., \& Fox, C. R. (2011). Behavioral strategy. Strategic Management Journal, 32(13), 13691386.

Rasid, S. Z. A., Isa, C. R., \& Ismail, W. K. W. (2014). Management accounting systems, enterprise risk management and organizational performance in financial institutions. Asian Review of Accounting, 22(2), 128-144.

Rotter, J. B. (1966). Generalized expectancies for internal versus external control of reinforcement. Psychological Monographs: General and Applied, 80(1), 1.

Sarstedt, M., Ringle, C. M., \& Hair, J. F. (2017). Partial least squares structural equation modeling. Handbook of Market Research, 26, 1-40.

Segev, E. (1987). Strategy, strategy-making, and performance in a business game. Strategic Management Journal, $8(6), 565-577$.

Seo, K., \& Sharma, A. (2018). CEO overconfidence and the effects of equity-based compensation on strategic risk-taking in the US restaurant industry. Journal of Hospitality \& Tourism Research, 42(2), 224 259.

Sirén, C., Patel, P. C., Örtqvist, D., \& Wincent, J. (2018). CEO burnout, managerial discretion, and firm performance: The role of CEO locus of control, structural power, and organizational factors. Long Range Planning, 51(6), 953-971.

Soin, K., \& Collier, P. (2013). Risk and risk management in management accounting and control. Elsevier.

Song, J. H. (1982). Diversification strategies and the experience of top executives of large firms. Strategic Management Journal, 3(4), 377-380.

Strauß, E., \& Zecher, C. (2013). Management control systems: a review. Journal of Management Control, 23(4), 233-268.

Taylor, R. N. (1975). Age and experience as determinants of managerial information processing and decision making performance. Academy of Management Journal, 18(1), 74-81.

Wangrow, D. B., Schepker, D. J., \& Barker III, V. L. (2015). Managerial discretion: An empirical review and focus on future research directions. Journal of Management, 41(1), 99-135.

Wei, L.-Q., Lau, C.-M., Young, M. N., \& Wang, Z. (2005). The impact of top management team demography on firm performance in China. Asian Business \& Management, 4(3), 227-250.

Wijesinghe, D., \& Samudrage, D. (2016). Top Manager Orientation, Management Accounting Systems and Strategy Implementation: Evidence from the Sri Lankan Manufacturing Sector. NSBM Journal of 
Management, 1(1).

Winter, P. (2007). Managerial Risk Accounting and Control-A German Perspective. Available at SSRN 1117205.

Wold, H. (1980). Model construction and evaluation when theoretical knowledge is scarce: Theory and application of partial least squares. In Evaluation of econometric models (pp. 47-74). Elsevier.

Zor, U., Linder, S., \& Endenich, C. (2019). CEO characteristics and budgeting practices in emerging market SMEs. Journal of Small Business Management, 57(2), 658-678. 